\title{
MUTU MANAJEMEN PROSES PEMBELAJARAN SEKOLAH MENENGAH KEJURUAN
}

\author{
Yayat Sudaryat \\ Dosen FIP Universitas Pendidikan Indonesia \\ email: y_sudaryat@yahoo.com
}

\begin{abstract}
ABSTRAK
Pokok masalah yang diteliti adalah apakah faktor-faktor input yang yang meliputi Kinerja Kepala Sekolah, Pembiayaan, Kemitraan, Manajemen Sekolah, Sarana/Prasarana, dan Implementasi Kurikulum berpengaruh terhadap kinerja tenaga pendidik dan perilaku peserta didik serta mutu manajemen proses pembelajaran di SMK berstandar nasional (SSN) dan sekolah unggulan Eks. RSBI di Jawa Barat. Penelitian ini deskriptif dan verifikatif, dengan metode survey explanatory. Pengolahan data menggunakan Analisis Regresi Multipel. Data dikumpulkan dari persepsi guru melalui kuesioner dengan populasi sebanyak 1.910 guru, dengan sampel 320 responden. Hasil penelitian secara deskriptif menunjukkan bahwa pada umumnya SMK SSN dan SMK unggulan eks RSBI di Jawa Barat: (1) memiliki kepala sekolah dengan kinerja tinggi (yang dicirikan oleh Kompetensi Instruksional, Manajerial, Kewirausahaan, Supervisi, Kepribadian, Kompetensi Sosial); (2) Pembiayaan dipersepsi sudah tinggi (meliputi: Perencanaan Biaya, Penggunaan Biaya dan Pertanggungjawaban); (3) pelaksanaan Kemitraan tinggi (meliputi: MoU, Penyusunan Program, Pelaksanaan Praktek dan Penilaian/Sertifikasi), (4) Manajemen Sekolah tinggi (meliputi: Perencanaan Strategis, Implementasi Program dan Evaluasi Program Sekolah; (5) memiliki Sarana Prasarana tinggi (meliputi: Sarana Fisik, Media Pembelajaran, Perpustakaan \& Laboratorium, Fasilitas Praktek, Sarana Teknologi Informasi), (6) Implementasi Kurikulum tinggi (meliputi: Tujuan dan Sasaran, Muatan Kurikulum, Aktivitas Pembelajaran, Evaluasi Kurikulum), (7) Kinerja Tenaga Pendidik tinggi (meliputi: Kompetensi Pedagogik, Kepribadian, Sosial dan Profesional), (8) Perilaku Peserta Didik tinggi (meliputi: Potensi, Motivasi, Aktivitas, dan Kepuasan (9) Mutu manajemen proses pembelajaran tinggi (meliputi: Perencanaan; Pelaksanaan; Penilaian; Pembelajaran Aktif dan Pengawasan). Hasil pengujian hipotesis menunjukkan bahwa: Kinerja Kepala Sekolah, Pembiayaan, Kemitraan, Manajemen Sekolah, Sarana/Prasarana, dan Implementasi Kurikulum berpengaruh kuat, positif, dan signifikan terhadap Kinerja Tenaga Pendidik dan peserta didik yang muaranya pengaruh terhadap mutu manajemen proses pembelajaran di SMK berstandar nasional (SSN) dan sekolah unggulan Eks. RSBI di Jawa Barat di Jawa Barat. Kata kunci: mutu manajemen, proses pembelajaran
\end{abstract}

\section{ABSTRACT}

The main problem to be investigated is whether the input factors covering Principals' competences, Financing, Partnership, School Management, Facilities/Infrastructure and Curriculum Implementation have effects on teachers and students competences as well as learning process quality in the Vocational High Schools considered as National Standard and the Outstanding Schools (ex pioneering schools conforming to International Standard). This research is the descriptive and verificative survey adopting the explanatory survey method. The data was processed applying Path Analysis Models and was collected from teachers' perception with the total population of 1920. Samples are three hundred and twenty respondents. The result of the research descriptively shows that the dominant factors affecting the quality of learning process in the National Standard Vocational Schools and the Outstanding Schools (ex pioneering schools conforming to international Standard) in west Java are considered to have high category, namely: 1) Principals' competences (including Instructional Competence, Managerial, Entrepreneurship, Supervision, Personality, and Social Competences); 2) Financing (including Planning, the use of finance, and accountability); 3) Partnership (in terms of MoU, program design, implementation of practices and Evaluation/Certification); 4) School management (including strategic planning, Program Implementation, School Program Evaluation); 5) Facilities and Infrastructure (including Physical facilities, Learning Media, Library and laboratories, facilities for practical work and facilities for Information Technology); 6) Curriculum Implementation (including the goals and the aims, curriculum content, Learning Activities, and Curriculum evaluation) 7) Teachers' competences (including Pedagogic, Personality, Social and Professional Competences); 8) students' attitude (in terms of Potential, Motivation, Activities, and Satisfaction); 9) quality of learning process (including Planning, Implementation, Active Learning, and Supervision). The result of the hypothesis test indicates that The Principal competences, Financing, Partnership, School Management, Facilities/Infrastructure, and the Curriculum Implementation have strong, positive, and significant effects on the teachers/educators' competence and the students which then give effect to the quality of learning process in the vocational high schools with national standard and the outstanding schools (ex pioneering school conforming to international Standard) in West Java.

Keywords: management quality, learning process 


\section{PENDAHULUAN}

Salah satu bentuk pendidikan nasional pada jenjang menengah, adalah Sekolah Menengah Kejuruan (SMK), seperti ditegaskan pada Pasal 15 yakni; "Pendidikan kejuruan merupakan pendidikan menengah yang mempersiapkan peserta didik terutama untuk bekerja dalam bidang tertentu". Tujuan SMK dapat diuraikan Menyiapkan siswa agar memiliki kepribadian yang bermoral dan beretika sehingga mampu meningkatkan kualitas hidup, menguasai dan mengikuti perkembangan teknologi, Menyiapkan siswa menjadi tenaga kerja yang terampil produktif untuk dapat mengisi lowongan kerja yang ada dan mampu menciptakan lapangan kerja. Lulusan SMK harus "mampu bekerja, mandiri/mampu berwirausaha, dan dapat melanjutkan ke perguruan tinggi."

Fungsi dan tujuan tersebut menunjukkan bahwa pendidikan di Sekolah Menengah Kejuruan harus diselenggarakan secara sistematis agar tujuan tersebut dapat dicapai. Mutu penyelenggaraan pendidikan dapat dilihat dari beberapa indikator. Beberapa indikator mutu hasil pendidikan diantaranya adalah nilai Ujian Nasional (UN), persentase kelulusan, angka drop out (DO), angka mengulang kelas, persentase lulusan yang bekerja, lulusan yang mampu berwirausaha dan menciptakan lapangan kerja serta melanjutkan ke jenjang pendidikan yang lebih tinggi. Kenyataan yang terjadi ukuran keberhasilan tersebut belum busa dicapai di SMK. Pernyataan tersebut sangat dilematis. Di satu pihak, begitu banyak persoalan yang sedang dan akan dihadapi SMK karena pemerintah akan memperbanyak pengembangan Sekolah Menengah Kejuruan (SMK) serta mengurangi pengembangan dan jumlah Sekolah Menengah Umum (SMU) sehingga pada tahun 2009 rasio perbandingan SMK dan SMU menjadi 60:40, dengan target tahun 2020 menjadi 70:30. Di pihak lain mutu lulusan masih sangat rendah, persoalan akan bertambah rumit karena penyerapan tenaga kerja tidak akan seimbang dengan keluaran sehingga akan menyebabkan tingkat pengangguran yang makin tinggi. Badan Pusat Statistik (BPS) dalam laporan bulan Agustus 2011, menyatakan jumlah angkatan kerja pada Agustus 2011 mencapai 117,4 juta orang, dan Tingkat Pengangguran Terbuka (TPT) di Indonesia pada Agustus 2011 mencapai 6,56 \% atau 7,70 juta, dimana sebanyak 3,07 juta adalah lulusan SLTA dan SMK. Dengan perbandingan jumlah antara SMA dan SMK di Indonesia 51:49 dapat diartikan bahwa jumlah TPT untuk lulusan SMA kurang lebih mencapai 1,56 juta dan jumlah TPT untuk lulusan SMK 1,51 juta. Menurut Balibang Puskur (2010), untuk mengurangi angka pengangguran, salah satu cara yang dapat dilakukan adalah perlu dikembangkannya karakter kewirausahaan sedini mungkin, karena suatu bangsa akan maju apabila jumlah wirausahanya paling sedikit 2\% dari jumlah penduduk. Pada tahun 2007, jumlah wirausaha di Singapura ada sebesar 7,2\%, Amerika Serikat 2,14\%, Indonesia yang mana jumlah penduduknya kurang lebih sebesar 220 juta, jumlah wirausahanya sebanyak 400.000 orang $(0,18 \%)$, yang seharusnya sebesar 4.400 .000 orang. Berarti Indonesia kekurangan sebesar 4 Juta orang wirausaha.

Arifah (2013:8) menjelaskan bahwa pada dasarnya lulusan SMK juga dapatmelanjutkan ke perguruan tinggi (PT), walaupun secara skematik mereka dapat menjadi pekerja atau berwirausaha. Kurang lebih 20 persen lulusan SMK pada tahun 2012-2013 telah melanjutkan ke perguruan tinggi. Lulusan tersebut berebut kursi Perguruan Tinggi dengan lulusan SMA/MA.

Beberapa fenomena tersebut menjadi ukuran bahwa mutu lulusan SMK secara umum relatif rendah. Dalam hal ini tidak dibedakan apakah lulusan dari SMK swasta atau negeri dengan kategori biasa (belum SSN), SMK dengan kategori standar (SSN) .atau sekolah dengan kategori unggulan . 
Bertitik tolak dari uraian tersebut maka yang akan menjadi pocus penelitian ini adalah mutu proses pembelajaran yang menjadi variabel terikat. Dalam penelitian ini dibahas mengenai mutu pendidikan dengan fokusnya pada mutu proses pembelajaran. Adapun objek yang diteliti adalah SMK dengan kategori SSN dan SMK Eks RSBI di Jawa Barat. Dalam penelitian ini menetapkan komponen dominan yang mempengaruhi mutu proses pembelajaran sebagai variabel input yang meliputi: Kompetensi Kepala Sekolah, Sarana Prasarana, Manajemen, Kemitraan, Pembiayaan, dan Implementasi kurikulum sebagai Variabel input. Adapun sebagai variabel proses adalah variabel mutu pembelajaran yang meliputi: Tenaga pendidik, Peserta Didik dan Mutu Proses pembelajaran

Rumusan masalah/masalah yang diteliti:

1. Bagaimana gambaran empirik komponen-komponen (1) Kompetensi Kepala Sekolah; (2) Pembiayaan; (3) Kemitraan/Peran Serta Masyarakat; (4) Manajemen Sekolah; (5) Sarana/ prasarana; (6) Implementasi kurikulum; (7) Tenaga Pendidik; (8) Peserta Didik dan (9) Mutu Proses Pembelajaran pada sekolah unggulan dan sekolah standar di Jawa Barat.

2. Apakah variabel input yang meliputi (1) Kompetensi Kepala Sekolah; (2) Pembiayaan; (3) Kemitraan/Peran Serta Masyarakat; (4) Manajemen Sekolah; (5) Sarana/prasarana; (6) Implementasi kurikulum berpengaruh terhadap variabel proses Tenaga Pendidik di Sekolah berstandar nasional (SSN) dan sekolah unggulan Eks. RSBI di Jawa Barat.

3. Apakah variabel input yang meliputi (1) Kompetensi Kepala Sekolah; (2) Pembiayaan; (3) Kemitraan/Peran Serta Masyarakat; (4) Manajemen Sekolah; (5) Sarana/prasarana; (6) Implementasi kurikulum berpengaruh terhadap variabel proses Peserta Didik di Sekolah berstandar nasional (SSN) dan sekolah unggulan Eks. RSBI di Jawa Barat.

4. Apakah variabel input yang meliputi (1) Kompetensi Kepala Sekolah; (2) Pembiayaan; (3) Kemitraan/Peran Serta Masyarakat; (4) Manajemen Sekolah; (5) Sarana/prasarana; (6) Implementasi kurikulum melalui variabel Tenaga Pendidik dan Peserta Didik berpengaruh terhadap Mutu Proses Pembelajaran di sekolah berstandar nasional (SSN) dan sekolah unggulan Eks. RSBI di Jawa Barat.

Kerangka Penelitian; Hubungan dan keterkaitan variabel yang diteliti digambarkan dalam variabel input dan variabel process. Variabel input terdiri atas: Kompetensi Kepala Sekolah, Pembiayaan, Kemitraan, Manajemen Sekolah, Sarana/Prasana dan Implementasi Kurikulum, sedangkan

Variabel Proses terdiri dari Kompetensi Tenaga pendidik, Peserta didik, dan Mutu Proses Pembelajaran Hubungan fungsional antar variabel penelitian tersebut tampak pada gambar 1 .

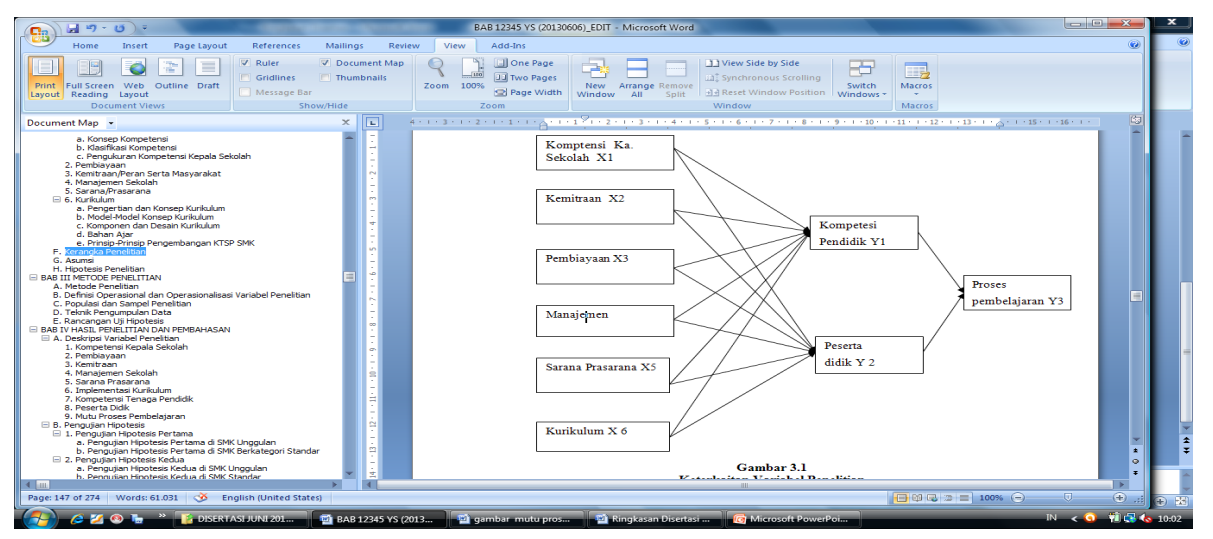

Gambar 1.

Kerangka dan Hubungaan Variabel Penellitian 


\section{METODE PENELITIAN}

Berdasarkan tingkat penjelasan dan bidang penelitian, jenis penelitian ini adalah penelitian deskriptif dan verifikatif. Husain Umar (2001: 21) menjelaskan bahwa "Penelitian dengan menggunakan metode deskriptif adalah penelitian yang dilakukan untuk mengetahui nilai variabel mandiri, Penelitian deskriptif di sini bertujuan untuk memperoleh deskripsi atau gambaran mengenai faktor-faktor yang mempengaruhi mutu proses pembelajaran dan implikasinya terhadap mutu lulusan SMK. Adapun sifat penelitian yang verifikatif pada dasarnya ingin menguji kebenaran dari suatu hipotesis yang dilaksanakan melalui pengumpulan data di lapangan.

\section{Populasi dan Sampel penelitian}

Yang menjadi unit analisis dalam penelitian ini adalah guru-guru pada Sekolah Menengah Kejuruan Negeri berstatus eks RSBI dan SSN bidang studi keahlian Teknologi dan Rekayasa di Provinsi Jawa Barat, yaitu sebanyak 17 RSBI dan 30 SSN, dengan jumlah guru sebanyak 478 guru RSBI dan 1432 guru SSN, sehingga secara keseluruhan populasi guru adalah sebanyak 1.910 dari 47 sekolah (RSBI dan SSN). Dengan demikian sampel dalam penelitian ini adalah sebagian dari populasi penelitian, yaitu sebagian dari guru SMKN bidang studi keahlian Teknologi dan Rekayasa. Yang menjadi populasi pada penelitian ini adalah 1910 guru, yang terdiri atas 690 guru SMK unggulan (Eks. RSBI) ditetapkan sampelnya 116, dan 1220 guru SSN ditetpkan sampelnya 204 orang.

\section{HASIL DAN PEMBAHASAN}

\section{Deskripsi Variabel Hasil Penelitian Kompetensi Kepala Sekolah}

Variabel Kompetensi Kepala Sekolah (X1) dibentuk oleh enam dimensi, yaitu: (1) Kompetensi Instruksional, (2) Kompetensi Manajerial, (3) Kompetensi Kewirausahaan, (4) Kompetensi Supervisi, (5) Kompetensi
Kepribadian, dan (6) Kompetensi Sosial. Rekapitulasi jawaban responden yang merupakan persepsi guru terhadap tingkat kompetensi Kepala Sekolah capaian persentase rata rata untuk SMK unggulan (Eks. RSBI ) 83,29, dan untuk SMK standar (SSN ) 75,5.

a. Pembiayaan

Variabel Pembiayaan (X2) dibentuk oleh tiga dimensi, yaitu (1) Perencanaan Biaya, (2) Penggunaan Biaya, dan (3) Pertanggungjawaban Rekapitulasi jawaban responden yang merupakan persepsi guru terhadap tingkat Pembiayaan capaian persentase rata rata untuk SMK unggulan (Eks. RSBI) 76,95, dan untuk SMK standar (SSN) 72,54. Ada perbedaan capaian rata persentase SMK unggulan dan standar yang menunjukkan bahwa kecenderungan Pembiayaan Sekolah unggulan (eks$\mathrm{RSBI})$ relatif lebih baik dibandingkan SMK standar (SSN). dilihat dari aspek perencanaan, penggunaan, maupun pertanggungjawabannya. persentase capaian keduanya masuk dalam kategori tinggi

\section{b. Kemitraan}

Variabel Kemitraan (X3) dibentuk oleh empat dimensi, yaitu (1) MoU, (2) Penyusunan Program, (3) Pelaksanaan Praktek, dan (4) Penilaian. Rekapitulasi jawaban responden yang merupakan persepsi guru terhadap tingkat Kemitraan capaian persentase rata rata untuk SMK unggulan (Eks. RSBI) 76,95, dan untuk SMK standar (SSN) 71,3 4. Ada perbedaan capaian rata persentase SMK unggulan dan standar dan yang menunjukkan bahwa kecenderungan program Kemitraan Sekolah unggulan (eks-RSBI) relatif lebih baik dibandingkan SMK standar (SSN). dilihat dari aspek MOU, Penyusunan Program, Pelaksanaan praktek dan Penilaian. Walaupun demikian persentase capaian keduanya masuk dalam kategori tinggi c. Manajemen Sekolah 
Variabel Manajemen Sekolah (X4) dibentuk oleh tiga dimensi, yaitu (1) Perencanaan Strategis Sekolah, (2) Implementasi Program Sekolah, dan (3) Evaluasi Program Sekolah. Rekapitulasi jawaban responden yang merupakan persepsi guru terhadap tingkat Kemitraan capaian persentase rata rata untuk SMK unggulan (Eks. RSBI) 77,05, dan untuk SMK standar (SSN) 70,00. Ada perbedaan capaian rata persentase SMK unggulan dan standar dan yang menunjukkan bahwa kecenderungan manajemen Sekolah unggulan (eks-RSBI) relatif lebih baik dibandingkan SMK standar (SSN). dilihat dari aspek Perencanaan Strategis Sekolah, Implementasi Program Sekolah, dan Evaluasi Program Sekolah. Walaupun demikian persentase capaian keduanya masuk dalam kategori tinggi.

\section{d. Sarana Prasarana}

Variabel Sarana Prasarana (X5) dibentuk oleh lima dimensi, yaitu (1) Sarana Fisik, (2) Media Pembelajaran, (3) Perpustakaan \& Laboratorium, (4) Fasilitas Praktek, dan (5) Sarana Teknologi Informasi (TI). Rekapitulasi jawaban responden yang merupakan persepsi guru terhadap kondisi sarana prasarana capaian persentase rata rata untuk SMK unggulan (Eks. RSBI) 75,34, dan untuk SMK standar (SSN) 73,07. Ada perbedaan capaian rata persentase SMK unggulan dan standar dan yang menunjukkan bahwa kecenderungan sarana prasarana Sekolah unggulan (eks-RSBI) relatif lebih baik dibandingkan SMK standar (SSN). dilihat dari aspek sarana pisik, Media Pembelajaran, Perpustakaan dan Laboratorium, Fasilitas Praktek dan sarana Teknologi Informasi. Walaupun demikian persentase capaian keduanya masuk dalam kategori tinggi

\section{e. Implementasi Kurikulum}

Variabel Implementasi Kurikulum (X6) dibentuk oleh empat dimensi, yaitu (1) Tujuan dan Sasaran, (2) Muatan Kurikulum
(3) Aktivitas Pembelajaran, dan (4) Evaluasi Kurikulum. Rekapitulasi jawaban responden yang merupakan persepsi guru terhadap kondisi sarana prasarana capaian persentase rata rata untuk SMK unggulan ( Eks. RSBI ) 74,77, dan untuk SMK standar (SSN) 72,05. Tidak perbedaan yang signifikan pencapaian rata persentase SMK unggulan dan standar dan yang menunjukkan bahwa implementasi kurikulum Sekolah unggulan (eks-RSBI) relatif sama dibandingkan SMK standar (SSN). dilihat dari aspek Tujuan dan Sasaran, Muatan Kurikulum, Aktivitas Pembelajaran, dan Evaluasi Kurikulum. Persentase capaian keduanya masuk dalam kategori tinggi

f. Kompetensi Tenaga Pendidik

Variabel Kompetensi Tenaga Pendidik (Y1) dibentuk oleh empat dimensi, yaitu (1) Kompetensi Pedagogik, (2) Kompetensi Kepribadian) Kompetensi Sosial, dan (4) Kompetensi Profesional. Rekapitulasi jawaban responden yang merupakan persepsi guru terhadap kondisi sarana prasarana capaian persentase rata rata untuk SMK unggulan (Eks. RSBI) 77,52, dan untuk SMK standar (SSN) 70,16. Ada perbedaan capaian rata persentase SMK unggulan dan standar dan yang menunjukkan bahwa kecenderungan Kompetensi tenaga Pendidik Sekolah unggulan (eks-RSBI) relatif lebih baik dibandingkan SMK standar (SSN). dilihat dari aspek Kompetensi Pedagogik, Kompetensi Kepribadian, Kompetensi Sosial, dan Kompetensi Profesional. Walaupun demikian persentase capaian keduanya masuk dalam kategori tinggi

\section{g. Peserta Didik}

Variabel Peserta Didik (Y2) dibentuk oleh empat dimensi, yaitu (1) Potensi, (2) Motivasi, (3) Aktivitas, dan (4) Kepuasan Rekapitulasi jawaban responden yang merupakan persepsi guru terhadap kondisi sarana prasarana capaian persentase rata rata untuk SMK unggulan (Eks. RSBI) 80,42, dan untuk SMK standar (SSN) 68,54. Ada perbedaan antara keduanya relatif cukup signifikan. Tampak bahwa tingkat potensi siswa, motivasi dan aktivitas dan serta kepuasan 
siswa di sekolah unggulan jauh lebih tinggi dibandingkan sekolah berkategori standar. Walaupun demikian persentase capaian keduanya masuk dalam kategori tinggi

\section{h. Mutu Proses Pembelajaran}

Variabel Mutu Proses Pembelajaran (Y3) dibentuk oleh lima dimensi, yaitu: (1) Perencanaan; (2) Pelaksanaan; (3) Penilaian, (4) Pembelajaran Aktif; dan (5) Pengawasan, Rekapitulasi jawaban responden terhadap variabel ini, yang dihitung dari capaian rata-rata variabel Mutu Pembelajaran (Y3) persentase capaian sebesar $72,78 \%$ yang dapat dikelompokkan pada kategori tinggi.

Mengacu pada kondisi tersebut, dapat dinyatakan bahwa pada umumnya proses pembelajaran dinilai sudah tinggi.
Berkaitan dengan dimensi Perencanaan, responden menilai bahwa guru sudah dapat merumuskan tujuan pengajaran, memilih dan mengembangkan bahan pengajaran, merencanakan kegiatan belajar mengajar, termasuk di dalamnya merencanakan pendekatan dan metode pengajaran, langkahlangkah kegiatan belajar mengajar, alat dan sumber belajar. Di sini juga dinyatakan bahwa sebagian besar guru telah mampu merencanakan penilaian yang tepat untuk evaluasi pembelajaran secara keseluruhan.

\section{Pengaruh Variabel Input terhadap Variabel Proses}

Kriteria untuk mengukur tinggi-rendahnya hubungan dan pengaruh variabel eksogen terhadap variabel endogen pada tabel 1 .

Tabel 1

Kriteria Pengukuran Hubungan dan Pengaruh

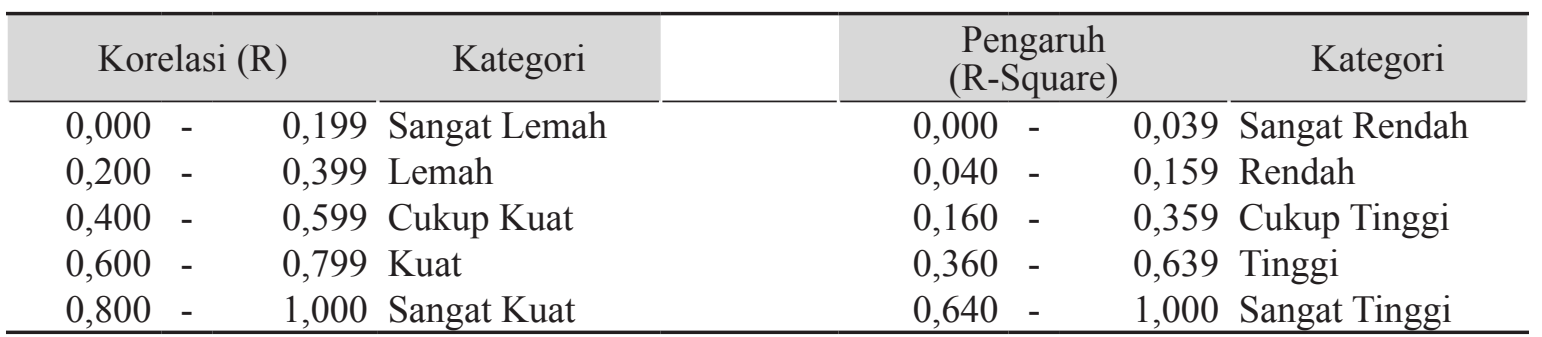

Sumber: Toharuddin (2012: 136)

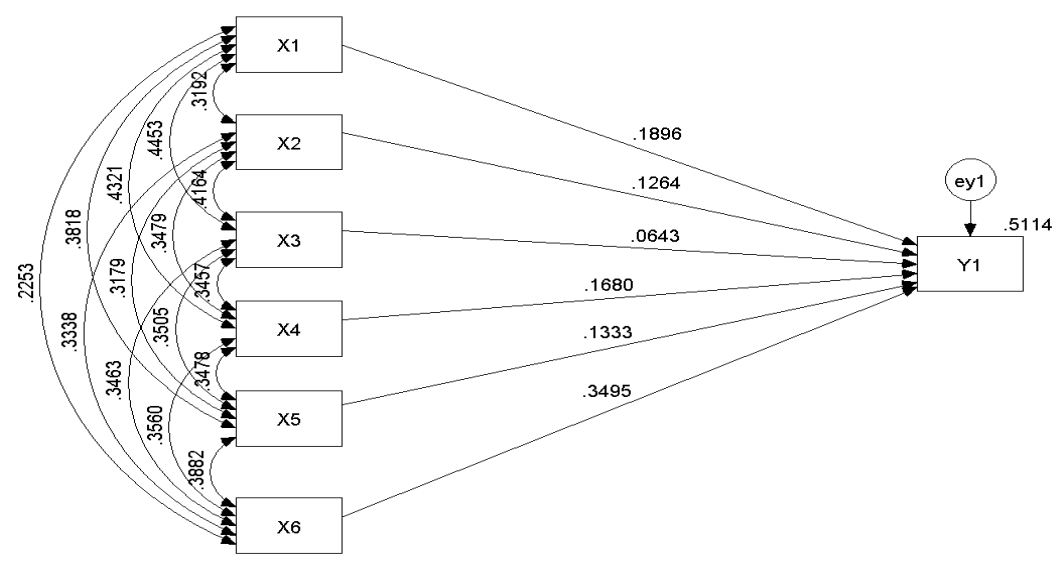

Gambar 2. Model Persamaan Struktural Pengaruh Variabel Input terhadapKompetensi Tenaga Pendidik dengan Koefisien Terstandarkan

\section{a. Pengaruh Variabel input terhadap terhadap Y1 ( TenagaPendidik )}

Pada bagian ini diuraikan hasil pengujian hipotesis pertama yang diajukan, yaitu "Kompetensi Kepala Sekolah, Pembiayaan, Kemitraan, Manajemen Sekolah, Sarana/
Prasarana, dan Implementasi Kurikulum berpengaruh terhadap Kompetensi Tenaga Pendidik di SMK berstandar nasional (SSN) dan sekolah unggulan Eks. RSBI di Jawa Barat di Jawa Barat". Pada gambar berikut disajikan model persamaan Analisis Jalur 
pengaruh variabel input terhadap variabel input Kompetensi Tenaga Pendidik (Y1) sebagai variabel endogen, dengan ukuran koefisien yang terstandarkan.

Hasil perhitungan analisis jalur dengan menggunakan SPSS-AMOS dapat disajikan pada gambar 2 .

Dari gambar tersebut dapat dilihat model

Tabel 2

Signifikansi Pengujian Hipotesis Pertama (Semua SMK)

\begin{tabular}{|c|c|c|c|c|c|c|c|}
\hline \multicolumn{3}{|c|}{ Jalur } & \multirow{2}{*}{$\begin{array}{r}\text { Estimasi } \\
0,1896 \\
\end{array}$} & \multirow{2}{*}{$\frac{S E}{0,0475}$} & \multirow{2}{*}{$\begin{array}{l}\text { t-hitung } \\
3,9909\end{array}$} & \multirow{2}{*}{$\begin{array}{l}\text { Nilai-p } \\
0,0000\end{array}$} & \multirow{2}{*}{$\frac{\text { Keterangan }}{\text { Signifikan }}$} \\
\hline Y1 & $<--$ & $\mathrm{X} 1$ & & & & & \\
\hline Y1 & $<---$ & $\mathrm{X} 2$ & 0,1264 & 0,0454 & 2,7856 & 0,0053 & Signifikan \\
\hline Y1 & $<---$ & $\mathrm{X} 3$ & 0,0643 & 0,0476 & 1,3515 & 0,1765 & Tidak Signifikan \\
\hline $\mathrm{Y} 1$ & $<---$ & $\mathrm{X} 4$ & 0,1680 & 0,0465 & 3,6111 & 0,0000 & Signifikan \\
\hline $\mathrm{Y} 1$ & $<--$ & $\mathrm{X} 5$ & 0,1333 & 0,0459 & 2,9030 & 0,0037 & Signifikan \\
\hline Y1 & $<---$ & X6 & 0,3495 & 0,0453 & 7,7169 & 0,0000 & Signifikan \\
\hline
\end{tabular}

Nilai t-hitung $\geq 1,9676$ atau nilai-p $\leq 0,05$ menunjukkan bahwa koefisien jalurnya signifikan. Dalam perhitungan tersebut, jalur $\mathrm{X} 1, \mathrm{X} 2, \mathrm{X} 4, \mathrm{X} 5$, dan X6 ke Y1 signifikan, sedangkan jalur X3 tidak signifikan. Hal ini menunjukkan bahwa Kompetensi Kepala Sekolah, Pembiayaan, Manajemen Sekolah, Sarana dan Prasarana, serta Implementasi Kurikulum memiliki pengaruh yang signifikan terhadap Kompetensi Tenaga Pendidik, sedangkan variabel Kemitraan (X3) tidak berpengaruh secara signifikan terhadap Kompetensi Tenaga Pendidik.

\section{b. Pengaruh Variabel Input terhadap Y2 ( Pesera Didik )}

Pada bagian ini diuraikan hasil pengujian hipotesis kedua yang diajukan, yaitu "Kompetensi Kepala Sekolah, Pembiayaan, Kemitraan, Manajemen Sekolah, Sarana/

Tabel 3

Signifikansi Pengujian Hipotesis Kedua (Semua Sekolah)

\begin{tabular}{|c|c|c|c|c|c|c|c|}
\hline \multicolumn{3}{|c|}{ Jalur } & \multirow{2}{*}{$\begin{array}{r}\text { Estimasi } \\
0,1775 \\
\end{array}$} & \multirow{2}{*}{$\begin{array}{l}\text { SE } \\
0,0488\end{array}$} & \multirow{2}{*}{$\begin{array}{r}\text { t-hitung } \\
3,6389 \\
\end{array}$} & \multirow{2}{*}{$\begin{array}{c}\text { Nilai-p } \\
0,0000 \\
\end{array}$} & \multirow{2}{*}{\begin{tabular}{l}
\multicolumn{1}{c}{ Keterangan } \\
Signifikan
\end{tabular}} \\
\hline $\mathrm{Y} 2$ & $<---$ & $\mathrm{X} 1$ & & & & & \\
\hline $\mathrm{Y} 2$ & $<---$ & $\mathrm{X} 2$ & 0,1586 & 0,0511 & 3,1018 & 0,0019 & Signifikan \\
\hline $\mathrm{Y} 2$ & $<---$ & $\mathrm{X} 3$ & 0,1062 & 0,0500 & 2,1253 & 0,0336 & Signifikan \\
\hline $\mathrm{Y} 2$ & $<---$ & $\mathrm{X} 4$ & 0,0974 & 0,0493 & 1,9745 & 0,0483 & Signifikan \\
\hline $\mathrm{Y} 2$ & $<---$ & $\mathrm{X5}$ & 0,1868 & 0,0487 & 3,8391 & 0,0000 & Signifikan \\
\hline $\mathrm{Y} 2$ & $<---$ & $\mathrm{X} 6$ & 0,2365 & 0,0510 & 4,6341 & 0,0000 & Signifikan \\
\hline
\end{tabular}
berpengaruh terhadap Peserta Didik di SMK berstandar nasional (SSN) dan sekolah unggulan Eks. RSBI di Jawa Barat di Jawa Barat". Pada gambar berikut disajikan model persamaan struktural pengaruh variabelvariabel input (X1 sampai X6) sebagai variabel eksogen terhadap variabel Peserta Didik (Y2) sebagai variabel endogen, dengan ukuran koefisien yang terstandarkan.

Dari gambar tersebut dapat dilihat model persamaan strukturalnya, yaitu:

$\mathrm{Y} 1=0,23625 \mathrm{X} 1+0,1775 \mathrm{X} 2+0,1586 \mathrm{X} 3+$ 0,1062 X4 + 0,0974 X5 + 0,1868 X6; dengan $\mathrm{R}^{2}=0,4359$

Estimasi, standar error, nilai t-hitung, nilai-p, dan signifikansi dari setiap koefisien jalurnya dapat disajikan tabel 3.

persamaan strukturalnya, yaitu:

Estimasi, standar error, nilai t-hitung, nilai-p, dapat disajikan sebagai berikut.

$\mathrm{Y} 1=0,1896 \mathrm{X} 1+0,1264 \mathrm{X} 2+0,0643 \mathrm{X} 3+$ $0,1680 \mathrm{X} 4+0,1333 \times 5+0,3495 \mathrm{X} 6$; dengan $\mathrm{R}^{2}=0,5114$

dan signifikansi dari setiap koefisien jalurnya 


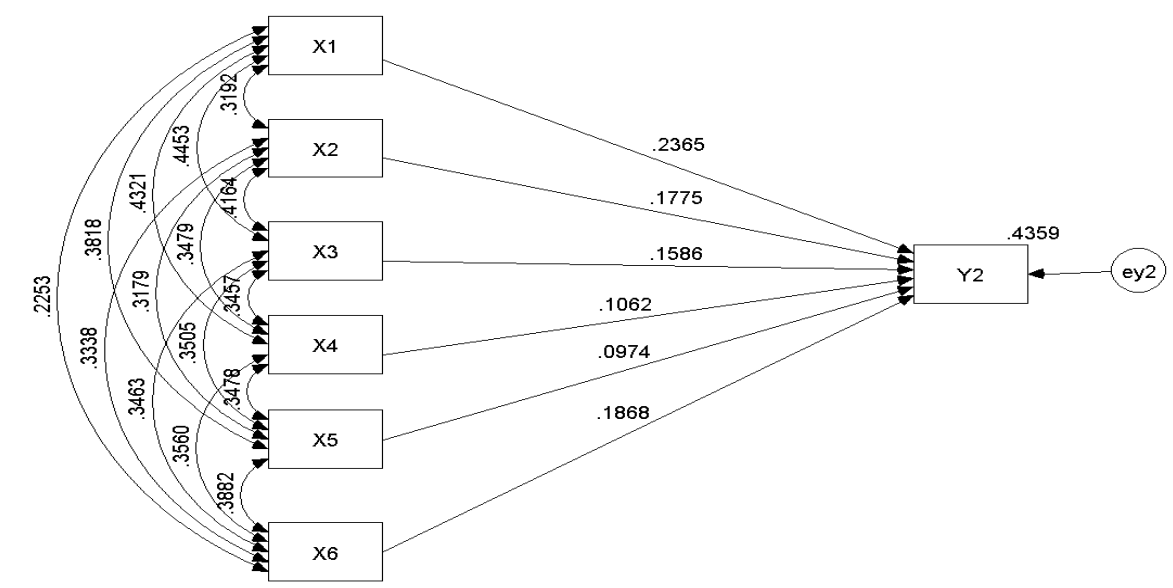

Gambar 3. Model Persamaan Struktural Pengaruh Variabel Input terhadap Peserta Didik dengan Koefisien Terstandarkan

Nilai t-hitung $\geq 1,9676$ atau nilai-p $\leq 0,05$ menunjukkan bahwa koefisien jalurnya signifikan. Dalam perhitungan tersebut, jalur X1, X2, X3, X4, X5, dan X6 ke Y2 signifikan. Hal ini menunjukkan bahwa Kompetensi Kepala Sekolah, Pembiayaan, Kemitraan, Manajemen Sekolah, Sarana dan Prasarana, serta Implementasi Kurikulum di SMKN bidang studi keahlian Teknologi dan Rekayasa di Provinsi Jawa Barat memiliki pengaruh yang signifikan terhadap Peserta Didik.

\section{Pengaruh Variabel Input melalui Kompetensi Tenaga Pendidik dan Peserta didik terhadap mutu proses pembelajaran}

Pada bagian ini diuraikan hasil pengujian hipotesis ketiga yang diajukan, yaitu "Kompetensi Kepala Sekolah, Pembiayaan, Kemitraan, Manajemen Sekolah. Sarana/ Prasarana, dan Implementasi Kurikulum melalui Kompetensi Tenaga Pendidik dan Peserta Didik berpengaruh terhadap Mutu Proses Pembelajaran di SMK berstandar nasional (SSN) dan sekolah unggulan Eks. RSBI di Jawa Barat di Jawa Barat".

\section{Pembahasan}

\section{a. Pengaruh Faktor-Faktor Input terhadap Kompetensi Tenaga Pendidik}

Pengujian hipotesis 1 menunjukkan bahwa faktor-faktor input secara keseluruhan memiliki pengaruh yang tinggi terhadap kompetensi tenaga pendidik.
Pengaruh variabel-variabel input yang relatif paling tinggi terhadap Kompetensi Tenaga Pendidik adalah Implementasi Kurikulum dengan koefisien jalur sebesar 0,3495, diikuti oleh Kompetensi Kepala Sekolah dengan koefisien jalur sebesar 0,1896, Manajemen Sekolah sebesar 0,1680, Sarana Prasarana sebesar 0,1333, dan Pembiayaan sebesar 0,1264 . Pengaruh yang paling kecil (dan tidak signifikan) adalah Kemitraan dengan koefisien jalur sebesar 0,0643.

\section{b. Pengaruh Faktor-Faktor Input terhadap Peserta Didik}

Pengujian hipotesis kedua menunjukkan bahwa faktor-faktor input secara keseluruhan memiliki pengaruh yang tinggi terhadap peserta didik

Pengaruh variabel-variabel input yang relatif paling tinggi terhadap Peserta Didik adalah Kompetensi Kepala Sekolah dengan koefisien jalur sebesar 0,2365, diikuti oleh Implementasi Kurikulum dengan koefisien jalur sebesar 0,1868, Pembiayaan sebesar 0,1775, Kemitraan sebesar 0,1586, dan Manajemen Sekolah sebesar 0,1062; Pengaruh yang relatif paling kecil adalah variabel Sarana Prasarana dengan koefisien jalur sebesar 0,0947.

\section{c. Pengaruh Faktor-Faktor Input melalui Kompetensi Tenaga Pendidik dan Peserta Didik terhadap Mutu Proses Pembelajaran}

Pengaruh faktor-faktor input melalui 
kompetensi tenaga pendidik dan peserta didik terhadap mutu proses pembelajaran menunjukkan bahwa pengaruh tenaga pendidik terhadap mutu proses pembelajaran merupakan faktor yang paling dominan, baik untuk SMK kategori unggul maupun kategori standar. Fungsi dan peran guru tersebut dapat berhasil karena guru mampu menerjemahkan dan mengimplementasikan kurikulum ke dalam silabus yang meliputi standar kompetensi, kompetensi dasar, indikator, pokok materi, pengalaman pembelajaran, dan strategi penilaian. Guru juga membuat RPP yang selanjutnya digunakan sebagai pedoman guru dalam mengajar, mulai dari membuka pelajaran, kegiatan inti, yang meliputi eksplorasi, elaborasi, dan konfirmasi, serta evaluasi. Hal ini menunjukkan bahwa tingginya implementasi kurikulum tersebut dapat mengembangkan kompetensi guru, terutama dalam kompetensi pedagogik dan profesional.

\section{d. Strategi Peningkatan Mutu Proses Pembelajaran}

Dari hasil penelitian dan pembahasan, berikut ini dapat disajikan model dan strategi peningkatan mutu proses pembelajaran. Peningkatan mutu pendidikan sangat dipengaruhi oleh kebijakan mutu yang antara meliputi: Visi, Misi dan strategi pendidikan sebagai arah tata-kelola dan pengembangan Pendidikan, pencapaian 8 Standar Nasional Pendidikan, Pelaksanaan Akreditasi Sekolah, Kebijakan Penjaminan Mutu Pendidikan yang secara kelembagaan dilakukan oleh LPMP, serta pengembangan Sistem Manajemen Mutu ISO 9000: 2000.
Upaya peningkatan kualitas pendidikan ini juga tidak bisa lepas dari pengaruh budaya sekolah serta lingkungan internal dan ekternal, juga pengendalian mutu. Indikator kualitas pendidikan tercermin dan akan terjadi jika di sekolah dapat berjalan suatu proses pembelajaran yang bermutu. Mutu proses pembelajaran ini akan terwujud jika didukung oleh input yang bermutu. Input tersebut meliputi: Kompetensi Kepala Sekolah, Kemitraan, Manajemen, Pembiayaan, Sarana Prasarana, dan Implementasi kurikulum. Sedangkan proses pembelajaran itu sendiri merupakan interaksi guru dan siswa untuk mengubah perilaku siswa agar mempunyai kompetensi dan kemandirian yang taksanominya meliputi pengetahuan, keterampilan, dan sikap. Perubahan perilaku dan kompetensi bisa dicapai dengan efektif jika proses pembelajaran melaksanakan pembelajaran aktif sesuai dengan Permendiknas Nomor 41 Tahun 2007 tentang Standar Proses untuk Satuan Pendidikan Dasar dan Menengah, yang menyatakan bahwa dalam kegiatan inti pembelajaran merupakan proses untuk mencapai Kompetensi Dasar (KD) yang harus dilakukan secara interaktif, inspiratif, menyenangkan, menantang, memotivasi peserta didik untuk berpartisipasi aktif, serta memberikan ruang yang cukup bagi prakarsa, kreativitas, dan kemadirian sesuai denganbakat, minat, dan perkembangan fisik dan psikologis peserta didik.

Secara keseluruhan, model peningkatan mutu proses pembelajaran di SMK dapat digambarkan sebagai berikut.

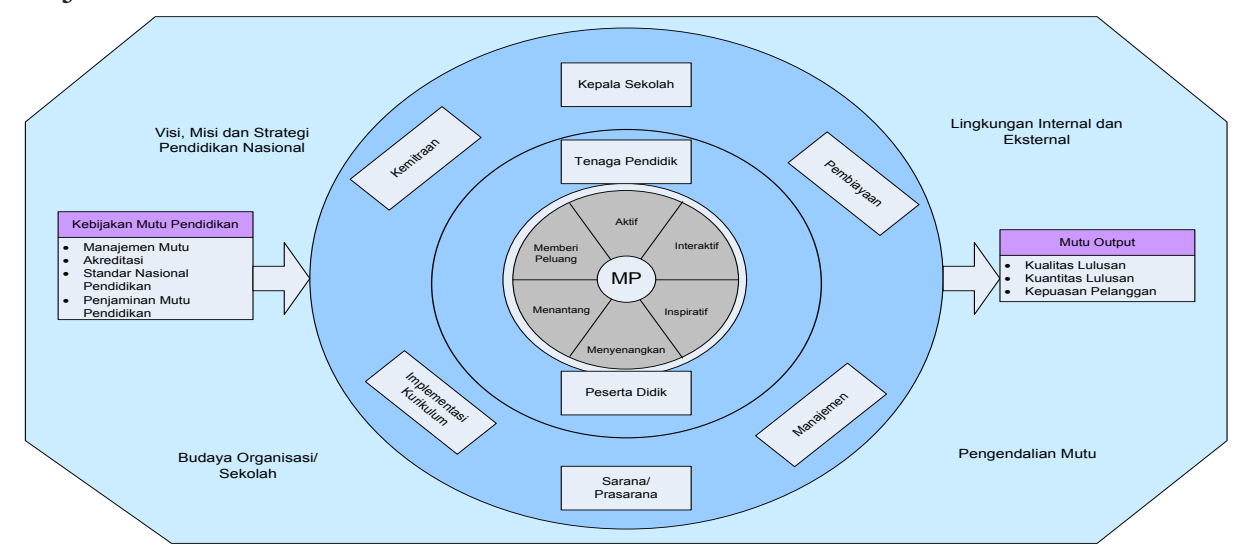

Gambar 4. Model Peningkatan Mutu Proses Pembelajaran di SMK. 


\section{KESIMPULAN}

Berdasarkan hasil analisis penelitian dan pembahasan, diperoleh beberapa kesimpulan sebagai berikut:

1. Variabel-variabel input yang meliputi: kompetensi kepala sekolah, pembiayaan, kemitraan, manajemen sekolah, sarana prasarana, implementasi kurikulum, dan variabel proses yang meliputi: kompetensi tenaga pendidik, peserta didik, dan mutu proses pembelajaran termasuk pada kategori tinggi. Hal ini menunjukkan bahwa secara keseluruhan, kondisi SMKN bidang studi keahlian Teknologi dan Rekayasa di Provinsi Jawa Barat dilihat dari variabel-variabel input maupun proses sudah baik dan harus terus dipertahankan walaupun dalam beberapa aspek masih ada kendala yang harus diatasi.

2. Secara keseluruhan, kompetensi kepala sekolah, pembiayaan, manajemen sekolah, sarana prasarana, implementasi kurikulum berpengaruh signifikan terhadap kompetensi tenaga pendidik, kecuali kemitraan tidak berpengaruh signifikan terhadap kompetensi tenaga pendidik. Dilihat dari kategori sekolah, semua variabel input di SMK unggulan berpengaruh positif terhadap kompetensi tenaga pendidik, sedangkan di SMK berkategori standar hampir semua berpengaruh kecuali variabel kemitraan.

3. Secara keseluruhan, kompetensi kepala sekolah, pembiayaan, kemitraan, manajemen sekolah, sarana prasarana, implementasi kurikulum berpengaruh signifikan terhadap peserta didik. Kecenderungan ini juga berlaku untuk SMK unggulan maupun SMK berkategori standar.

4. Secara keseluruhan, kompetensi kepala sekolah, pembiayaan, kemitraan, manajemen sekolah, sarana prasarana, implementasi kurikulum melalui kompetensi tenaga pendidik dan peserta didik berpengaruh secara signifikan terhadap mutu proses pembelajaran dengan kategori tinggi. Untuk SMK kategori unggul pengaruhnya sangat tinggi, sedangkan SMK kategori standar pengaruhnya termasuk pada kategori tinggi.

\section{DAFTAR PUSTAKA}

Abu-Duhou, I. (2003). School-Based Management (Manajemen Berbasis Sekolah). Buku Serial Dasar-dasar Perencanaan Pendidikan Terbitan UNESCO. Jakarta: Logos.

Alton-Lee, A. (2003). Quality teaching for diverse students in schooling: Best evidence synthesis. Wellington: Ministry of Education.

Banghart, F. W; Trull, Jr. Albert. (1973). Educational Planning. New York: The Mac Millan Company.

Bryson, J. M. 2000. (Alih Bahasa oleh M. Miftahudin). Perencanaan Strategis Bagi Organisasi Sosial. Yogyakarta: Pustaka Pelajar.

Daniel, Y. (2008). "Principal Leadership in New Teacher Induction: Becoming Agent of Change". International Journal of Education Policy \& Leadership, Vol. 3.

Daryanto, M. (1998). Administrasi Pendidikan. Jakarta: Rineka Cipta.

Dasuqi, D. A. dan Somantri, S. (1992). "Wawasan Dasar Pendidikan dan Wawasan Dasar Administrasi Pendidikan”. Dalam Administrasi Pendidikan. Bandung: Jurusan Administrasi Pendidikan, Fakultas Ilmu Pendidikan IKIP Bandung.

Departemen Pendidikan Nasional. 2003. Standar Kompetensi Nasional Bidang Keahlian Elektronika Manufaktur. Jakarta: Dirjen Dikdasmen.

Donmoyer, R., Imber, M., Scheurich, J.J., (1995). The Knowledge Base in Educational Administration Multiple Perspectives. New York: State University of New York Press, Albany.

Engkoswara. (2011). Dasar-dasar Administrasi Pendidikan. Jakarta: Depdikbud Ditjen Dikti Proyek Pengembangan Lembaga Pendidikan Tenaga Kependidikan. 
Handayaningrat, S. (1998). Pengantar Studi Ilmu Administrasi dan Manajemen. Jakarta: CV Haji Masagung.

Hutagalung, R. (2009). 'Pengertian Mutu, Manfaat dan Perkembangannya' tersedia: http://ekonomi.kompasiana. com/2009/11/03/pengertian-mutu-manfaat-dan-perkembangannya/ [retrieved: 02 Juni 2010].

Hoy, W. K. dan Miskel, C. G. (2001). Educational Administration Theory, Research, And Practice $6^{\text {th }}$ ed., International Edition, Singapore: McGraw-Hill Co.

Toharuddin, T. (2012). Analisis Data Kuantitatif dalam Penelitian Pendidikan. Jakarta: Litbang Dikdasmen. 